\title{
Refleksje o nauce historii prawa, jej „Czasopiśmie Prawno-Historycznym” i jego Redaktorze
}

Zachętę do napisania tych uwag stanowiły dwie okoliczności. Jednej z nich dostarczył skromny, ale istotny jubileusz - publikacja sześćdziesiątego szóstego tomu „Czasopisma Prawno-Historycznego”. Drugą stanowiła konferencja Komitetu Redakcyjnego „Czasopisma”. Odbyła się ona 9 września 2014 r. w Instytucie Historii Prawa Uniwersytetu Warszawskiego. Doprowadziła do dalszych dyskusji, niesformalizowanych i prowadzonych de omnibus rebus et quibusdam aliis, ale interesujących i wartościowych. Obydwie te okoliczności zasługują na omówienie.

„Czasopismo Prawno-Historyczne” (w dalszym ciągu niniejszego tekstu przytaczane w skrócie: CPH), powołane zostało do życia po drugiej wojnie światowej, w 1948 roku. Twórcy CPH, oddając do rąk czytelników jego pierwszy tom, stwierdzili: „Nie sądzimy, aby racje tego przedsięwzięcia potrzeba było długo uzasadniać". I Ich opinię podzielali następcy, wydający CPH przez kilkadziesiąt lat, aż do naszych czasów².

Tworzyli CPH badacze z pokolenia, które jeszcze brało udział w odbudowie Rzeczypospolitej po pierwszej wojnie światowej, uczestniczyło w pracy nad tworzeniem jej ustroju i w kodyfikowaniu jej prawa. Odsunięci od

${ }^{1}$ Była to opinia pierwszych redaktorów CPH, profesorów Zygmunta Lisowskiego i Zygmunta Wojciechowskiego (CPH, t. I, Poznań 1948 r., s. 1).

${ }^{2}$ W latach 1948-1949 redagowali CPH profesorowie Zygmunt Lisowski, Zygmunt Wojciechowski i Karol Koranyi, z pomocą sekretarza Michała Sczanieckiego. Do roku 1951 redaktorem był Zygmunt Wojciechowski, sekretarzem Michał Sczaniecki. W latach 1953-1955 (przy czym od roku 1954 CPH stało się półrocznikiem) redaktorem był Michał Sczaniecki, sekretarzem Jan Wąsicki. W latach 1956-1968 redaktorami byli Michał Sczaniecki i Juliusz Bardach, sekretarzem Jan Wąsicki. W latach 1969-1977 redaktorem był Michał Sczaniecki, sekretarzem Henryk Olszewski. W latach 1978-1989 redaktorem był Henryk Olszewski, sekretarzem Bogdan Lesiński. Od roku 1988 do chwili dzisiejszej redaktorem jest Henryk Olszewski, ale często zmieniali się służący mu do pomocy sekretarze, lub też w ogóle nie posiadał sekretarza. O zmianie tego stanu rzeczy redaktor powiadomił Komitet Redakcyjny na konferencji w dniu 9 IX 2014 r. 
wpływów i znaczenia po drugiej wojnie światowej, nie cieszyli się zaufaniem władz Polski Ludowej i nie byli powoływani do pracy przy wprowadzaniu w życie zasad nauki marksistowskiej. Bynajmniej jednak nie zaprzestali pracy naukowej, przekazywali także uczniom i następcom swój warsztat naukowy i technikę pracy badawczej. Z czasem dochodziło do znaczenia pokolenie, które pogodzić się musiało z narzuconym Polsce ustrojem. Nie kwestionując obowiązujących założeń materializmu historycznego, spokojnie prowadziło swoje badania, zwłaszcza w zakresie popieranej odgórnie historii gospodarczo-społecznej i kontynuowało wielki dorobek polskiej historii prawa. Stopniowo też poddawano erozji dogmaty ideologii marksistowskiej, osłabiano cenzurę i w drodze ewolucyjnej przywracano swobodę nauki. Periodyk nasz służy już nauce nieprzerwanie od sześćdziesięciu sześciu lat. Opublikowane w nim zostały setki rozpraw, artykułów, materiałów, recenzji i not recenzyjnych, polemik, biografii, informacji kronikarskich. Pisali do CPH uczeni polscy, ale i badacze z wielu innych krajów, zwłaszcza Europy Środkowej. Ogromny ten dorobek zebrany został w bibliografiach, publikowanych przy życiorysach poszczególnych uczonych lub dodawanych jako osobne zeszyty $\mathrm{CPH}^{3}$. Ponadto profesor Jakub Sawicki, wykroczywszy poza ramy $\mathrm{CPH}$, publikował „Materiały do polskiej bibliografii historycznoprawnej”4.

Zespół dyscyplin naukowych historii prawa ma za sobą długą tradycję tworzył się bowiem w konsekwencji losów państwa polskiego. Studia nad nieskodyfikowanym prawem w Dawnej Rzeczypospolitej musiały mieć charakter historyczny; to samo dotyczyło obowiązujących w Koronie praw obcych. Z czasem, od schyłku XVIII wieku i w wieku XIX, studia te zająć się musiały państwem i prawem Monarchii Habsburskiej i Rzeszy Niemieckiej, Cesarstwa Napoleońskiego i Cesarstwa Rosyjskiego. Nim jeszcze doszło do wskrzeszenia państwa polskiego po pierwszej wojnie światowej, już toczyły się na ten temat dyskusje, a po nich i prace; odbudowa brać bowiem musiała pod uwagę pozytywne i negatywne doświadczenia epoki porozbiorowej i dorobek ustrojowy Europy XIX wieku. Niebawem druga wojna światowa, obydwie okupacje i powojenne losy poszerzyć musiały pole badawcze o ocenę międzywojennego dorobku, a zwłaszcza charakterystykę sąsiednich totalitaryzmów.

Ten przebieg procesu dziejowego spowodował, że w polskim programie studiów cztery wielkie dyscypliny historycznoprawne - prawo rzymskie

3 Por.: M. i H. Olszewscy, Bibliografia zawartości CPH za lata 1948-1967 (CPH, t. XX, z. 2 , 1968); R. Sobotka (z przedmową M. Zabłockiej), Bibliografia zawartości za lata 1948-1998 (CPH, t. L, z. 2, 1998); R. Sobotka (z przedmową A.B. Zakrzewskiego), Bibliografia zawartości za lata 1948-2013 (CPH, t. LXV, z. 2, 2013). Zawiera ona 4090 pozycji.

4 Jakub Sawicki (1899-1979), kanonista, profesor Uniwersytetów w Wilnie i w Warszawie, publikował te „Materiały” od tomu VI, z. 2 z 1954 r., do tomu XXXI, z. 1 z 1979 r. Po nim pracę tę kontynuowali Hubert Izdebski, Marek Wąsowicz i zwłaszcza Maria Zabłocka, z pomocą młodszych kolegów, aż do ostatnich lat. 
i oparte na nim prawo kanoniczne, powszechna i polska historia państwa i prawa, historia doktryn politycznych i prawnych - ściśle są z sobą powiązane zarówno merytorycznie, jak i organizacyjnie. Oczywistą jest więc rzeczą, iż służy im od lat jeden periodyk naukowy: $\mathrm{CPH}$.

Poświęcona mu, wspomniana we wstępie niniejszego tekstu konferencja miała bogaty program, składający się z dwóch części. W części pierwszej redaktor, profesor Henryk Olszewski złożył sprawozdanie z prac redakcyjnych nad CPH w roku akademickim 2013-2014. Profesor Maria Zabłocka podsumowała zawartość trzech zeszytów za ostatnie lata ${ }^{5}$, zwracając zwłaszcza uwagę na publikacje poświęcone prawu rzymskiemu, a redaktor zaprezentował przygotowaną już zawartość tomu LXVI, drugiego zeszytu za rok 2014. Nad prezentacjami tej części konferencji odbyła się dyskusja, w której głos zabierali wszyscy obecni na posiedzeniu członkowie Komitetu Redakcyjnego $^{6}$. Uległa ona poszerzeniu, znacznie przekraczając zaplanowane z góry granice. W drugiej części konferencji redaktor przedstawił sprawy organizacyjne, które wywołały kolejną dyskusję, dotyczącą aktualnej problematyki dyscyplin prawnohistorycznych. Dyskusja zakończyła się wnioskiem, o którym będzie mowa poniżej.

$\mathrm{Z}$ dużą troską środowisko naukowe obserwuje tendencje do ograniczenia przedmiotów prawnohistorycznych w programach studiów uniwersyteckich. Jest to konsekwencja dążeń do przeobrażenia studium prawa w zawodową naukę aktualnie obowiązujących przepisów. W stosunku do dyscyplin takich jak filozofia, socjologia czy właśnie historia prawa, zapewniających całej dziedzinie prawdziwie uniwersytecki poziom, polega to głównie na zmniejszeniu ilości godzin wykładu. Pojawiły się pomysły, aby wbrew systemowi sprawdzonemu od pokoleń usunąc historię z pierwszego roku studiów (gdzie pełni ona rolę ,wprowadzenia” do zawodu). Jako wykład fakultatywny znalazłaby się na ostatnim roku studiów, a nieodzowny problem selekcji kandydatów złożyłoby się na barki przedmiotów takich jak prawo cywilne czy prawo karne. W ramach tych tendencji doszło nawet do całkowitej likwidacji przedmiotów prawnohistorycznych na jednym z uniwersytetów, mianowicie w Gdańsku.

Propozycje te są w głównej mierze skutkiem ogromnego rozwoju przedmiotów dogmatycznych, które domagają się zwiększenia swych godzin wykładowych. Nie biorą one pod uwagę oczywistego faktu, że poważny ,przyrost problematyki" nastąpił także w dziedzinie historii najnowszej - w polskim procesie ustrojowym granicą historii prawa stał się rok 1989. Wprawdzie zgodnie z centralną decyzją problematyka badawcza czasów okupacji oraz całej epoki PRL powierzona została nie środowisku uniwersyteckiemu, lecz

\footnotetext{
${ }^{5}$ Zeszyty 1 i 2 tomu LXV za rok 2013 i zeszyt 1 tomu LXVI za rok 2014.

${ }^{6}$ Pełen skład Komitetu Redakcyjnego podawany jest na verso karty tytułowej każdego zeszytu „Czasopisma”.
} 
odrębnemu Instytutowi Pamięci Narodowej ${ }^{7}$. Tymczasem właśnie zagospodarowanie całej epoki PRL-u to zadanie dla uniwersyteckiej historii państwa i prawa, wolnej od powierzchownych, publicystycznych ocen.

Powracając do problematyki konferencji z 9 września 2014 r., podkreślić należy rzecz oczywistą, że dorobek naukowy $\mathrm{CPH}$, publikowany w ostatnich latach, stanowi odbicie poziomu naszych dyscyplin po zmianie ustrojowej dokonanej w 1989 roku. W ujęciu przedstawionym przez profesor Marię Zabłocką, oraz uzupełnionym przez dyskutantów, przedstawia się on następująco.

Utrzymuje się godny podkreślenia rozwój nauki prawa rzymskiego, bynajmniej nie ograniczonego do roli propedeutyki prawa prywatnego. Kiedy przed kilkudziesięciu laty usiłowano ograniczyć prawo rzymskie, wtłaczając je w ramy przedmiotu określanego jako ,prawo antyczne”, zamiar ten na szczęście nie powiódł się. Obecnie doszło do sytuacji pod niektórymi względami przeciwstawnej. Doszło do znacznego poszerzenia bazy źródłowej w związku z rozwojem papirologii, sztuki czytania starożytnych tekstów grecko-łacińskich pisanych na papirusie; rozwijać się począł obraz, jak wyglądało prawo rzymskie w codziennym działaniu. Powróciło tradycyjne przekonanie, że Europa od schyłku starożytności aż po nasze czasy kształtowała się w nurcie kultury grecko-rzymskiej, której jednym z filarów było prawo rzymskie. Na jego podstawie rozwijało się od średniowiecza prawo kanoniczne, gdyż ecclesia vivit lege romana, a samo prawo rzymskie dostosowywało się do potrzeb praktyki w epoce nowożytnej. Kiedy pojawiły się tendencje integracyjne, w nauce europejskiej wzmocniły się badania nad prawem rzymskim jako wspólną podstawą narodowych systemów prawnych, ius gentium dla Unii Europejskiej. Także i w nauce polskiej studia ostatnich lat dowiodły, iż znaczenie prawa rzymskiego było większe, niż zazwyczaj przyjmowano; rozszerzało podstawę do badań nad dziejami kultury prawnej.

Średniowiecze, zarówno w polskiej, jak i w powszechnej historii państwa i prawa, stało się dziedziną coraz bardziej zaniedbywaną. W widoczny sposób maleje tu ilość opracowań, zgłaszanych do druku w CPH. W dyskusji pojawiły się nierealne pomysły, aby „służbowo" wręcz kierować do tej problematyki młodych doktorantów. Podobne zjawisko, choć nie w tak poważnym stopniu, dotyczy epok Odrodzenia i Baroku ${ }^{8}$.

${ }^{7}$ Wiąże się z tym nietypowa, nader dyskusyjna periodyzacja. Okres Drugiej Rzeczypospolitej rozpoczynający się w 1918 roku, kończy się w roku 1944. Okres Trzeciej Rzeczypospolitej zaczął się w 1989 roku. Okres PRL-u, zamknięty w latach 1944-1989 został jako niesuwerenny, usunięty poza nawias, w publicystyce niemalże jako „czarna dziura” w dziejach państwa i narodu. Tymczasem dotyczący tego okresu dorobek, choćby tylko ten, który publikowany jest w CPH, świadczy o poważnym rozwoju nauki polskiej.

${ }^{8}$ Od 1996 roku ukazuje się edycja „Volumina Constitutionum”. Ma ona zastąpić stare, zasłużone „Volumina Legum”. Jest ona opatrzona pełnym aparatem naukowym. Do 2013 roku ukazało się siedem zeszytów, zawierających materiał normatywny sejmu polskiego od schyłku XV do po- 
Niemało ukazuje się na łamach $\mathrm{CPH}$ publikacji z zakresu powszechnej historii państwa i prawa, choć tu terminus a quo wyznacza wielka rewolucja francuska. Rzut oka na budzące tu zainteresowanie problemy badawcze dowodzi, że w niewielkim stopniu sprawdziła się reforma dokonana po drugiej wojnie światowej. Dyscyplinie tej, wykładanej do 1939 roku przez profesora Stanisława Estreichera jako „Historia ustroju na zachodzie Europy”, stawiano zarzuty, że cechuje ją „okcydentalizm”. Miało to wówczas charakter nie naukowy, lecz polityczny, ale było groźnym zarzutem; oznaczał on, że nauka polska w niedostatecznym stopniu czerpie wzorce do naśladowania ze Związku Radzieckiego. Rozszerzono więc program wykładu, obejmując nim dzieje Rusi Kijowskiej oraz Rosji, aż do rewolucji październikowej włącznie. Wtedy właśnie pojawiła się nazwa przedmiotu: „Powszechna historia państwa i prawa”.

W niewielkim jednak stopniu uczeni polscy przejawili ochotę, iżby zwrócić się ku wschodowi. Ci, którzy się na to zdecydowali, natrafili na przeszkody. Dotarcie do archiwaliów, które umożliwiłyby badanie dziejów ustroju i prawa Rosji, napotykało na trudności. W ostatnich dopiero latach pewne osiągnięcia w tym zakresie zanotowała historia doktryn politycznych i prawnych.

Zdaniem dyskutantów, osłabienie procesu badań nad Średniowieczem i Odrodzeniem jest wynikiem słabszego przygotowania maturzystów w zakresie historii ogólnej oraz rezygnacji z łaciny. Jest to bardzo prawdopodobne. Jeśli przyjąć te przyczyny, to trzeba się będzie liczyć z tym, że ten kryzys będzie się pogłębiał i wyjście z niego stanie się z każdym rokiem trudniejsze.

Lepiej uprawiane są pola badawcze, dotyczące schyłku XVIII i całego XIX wieku; tu ilość publikacji, zgłaszanych do druku w CPH, utrzymuje się na wysokim poziomie. Zniknęły pozanaukowe przeszkody; podkreślić bowiem warto, że w epoce PRL im bardziej problematyka badawcza zbliżała się ku współczesności, tym bardziej interesowała się nią cenzura. Jednym z przykładów była data roku 1972, czyli dwustulecie pierwszego rozbioru Polski. Propozycje zorganizowania w związku z tym międzynarodowej, a choćby tylko krajowej konferencji natrafiła na trudności ${ }^{9}$.

Dyskutanci podkreślali, że nawet w odniesieniu do tej epoki obserwować można słabe przygotowanie filologiczne młodego pokolenia badaczy: niedostateczną znajomość języków francuskiego, niemieckiego, a zwłaszcza rosyjskiego. Ten ostatni, przez wiele dziesięcioleci PRL obowiązkowy od szkoły podstawowej aż po uniwersytet, niebawem wygasł, z braku dostępu do archiwaliów i literatury.

łowy XVII wieku. Wydawcy nie zauważyli jednak, aby udostępniony przez nich materiał źródłowy wpłynął na intensyfikację badań nad dziejami ustroju i prawa tej epoki.

${ }^{9} \mathrm{Z}$ tego też powodu zeszyty XXIV i XXV CPH problematyki tej nie omawiały, żadnych też rozpraw, choćby pośrednio dotyczących rocznicy pierwszego rozbioru, do redakcji CPH nie zgłoszono. 
Badacze, podejmujący problematykę ustrojową XX wieku, napotkali na problem ujmowania ustroju Drugiej Rzeczypospolitej w epoce PRL zdecydowanie krytycznie, jako „burżuazyjno-obszarniczego”. Przyszło więc tendencyjną tę opinię korygować, a także walczyć z szeregiem ujęć z pozoru tylko naukowych, w rzeczywistości zaś publicystycznych. Skomplikowała się też sytuacja tych, którzy podejmowali problematykę od drugiej wojny światowej. Powołany do życia Instytut Pamięci Narodowej skomplikował dostęp do archiwaliów, a popierana odgórnie ,,polityka historyczna” utrudniła prowadzenie obiektywnych badań niedalekiej przeszłości.

Poruszono również $\mathrm{w}$ dyskusji szereg spraw luźno już tylko wiążących się lub wcale nie związanych z dorobkiem CPH. Jedną z takich kwestii była luka pokoleniowa $\mathrm{w}$ środowisku badaczy historii państwa i prawa. Starsze, odchodzące już pokolenie różni się od następców nie tylko doświadczeniem i dorobkiem. Przeżywszy epokę obowiązującej ideologii marksistowskiej, jej ataku, rozkwitu, a następnie rozkładu, nabierali nieraz potem chłodnego i niechętnego stosunku do wszelkich dyskusji ,ideologicznych”. Nie unikali jednak syntez naukowych. Podejmując zwłaszcza prace nad podręcznikami obejmującymi całość danej dyscypliny (minęły czasy, kiedy we wszystkich uczelniach obowiązywał jeden podręcznik, uznawany przez władze $)^{10}$, publikowali wykłady według własnego ujęcia przedmiotu, odchodząc od obowiązujących w czasach PRL ujęć marksistowskich, zwłaszcza podziału procesu dziejowego na „formacje społeczno-ekonomiczne”. Wymagało to ujmowania danej dyscypliny w całości; nie dało się pozostawić na marginesie całych epok czy problemów.

Młodsze pokolenie, o czym świadczy wspomniana wyżej ucieczka od średniowiecza, a nawet i czasów nowożytnych, unikać poczęło ujęć syntetycznych, dużo natomiast zajmuje się produkcją naukową o charakterze przyczynkarskim. Nie jest to wynikiem braku ambicji - wielu z tych młodych ludzi wie, że Michał Bobrzyński swoje Dzieje Polski, opracowanie, które odegrało tak wielką rolę w nauce i w świadomości narodowej, pisał mając 29 lat. Owo rozmienianie się na drobne jest natomiast konsekwencją zasługujących na surową krytykę reform i metod porównawczych ocen, prowadzących do rankingów uczelni, czasopism, a nawet jednostek w oparciu o ,punkty”. Młodzi pracownicy naukowi wiedzą, że o ich awansach lub przyznawanych im grantach decydują nie ich wartościowe dzieła, lecz owe „punkty”.

$\mathrm{W}$ nauce, a przede wszystkim w jej dziedzinach humanistycznych, ocena osiągnięć badawczych w oparciu o ,,punktacje” jest działalnością nie tylko

10 Pięciotomowa Historia państwa i prawa Polski, autorstwa i pod redakcją Juliusza Bardacha, zbyt obszerna jak na potrzeby egzaminacyjne, ustąpiła miejsca dziełu Juliusza Bardacha, Bogusława Leśnodorskiego i Michała Pietrzaka: Historia ustroju i prawa polskiego. Wielotomowa Powszechna historia państwa i prawa Karola Koranyi'ego ustąpiła miejsca podręcznikowi Michała Sczanieckiego: Powszechnej historii państwa i prawa. 
błędną, ale i szkodliwą. Przecenia jedne osiągnięcia, pomijając inne; spowodowała na przykład odejście od prac edytorskich. Zawinione już to było przez praktykę wielu lat ubiegłych, polegającą na tym, że wydawnictwa źródłowe nie były brane pod uwagę jako podstawy w przewodach doktorskich i habilitacyjnych.

System punktacyjny już w tej chwili osiągnął skutek taki, że pracownikowi naukowemu bardziej się opłaca opublikować dwa-trzy artykuły (byle w wyżej punktowanym czasopiśmie), niż podjąć obszerny temat, napisać poważną monografię. Potwierdza tę sytuację fakt, iż do redakcji CPH napływa mało większych rozpraw, natomiast sporo drobnych, drugorzędnej często wartości artykułów.

Nie brakło w dyskusji uwag poświęconych krytyce naukowej. Stanowisko władz wprowadzających obowiązkowe recenzje, sporządzane według narzuconego schematu, nadto anonimowe, spotkało się z krytyką, posuwającą się aż do potępienia. Doświadczeni, zasłużeni badacze nie są skłonni oceniać anonimowo prac swych - nie tylko młodszych - kolegów. Praktyka przyjęta już od wieków polega na tym, że uczony bierze osobistą odpowiedzialność za opinię wyrażoną o pracy choćby nawet swego adwersarza. Recenzowany, obojętne czy idzie o doktorat, habilitację czy inną publikację, winien mieć prawo obrony, a czytelnik wyrobi sobie zdanie zgodnie z zasadą: audiatur et altera pars.

Nie warto dodawać, że w systemie ocen, obecnie wprowadzonym, zdarzać się mogą recenzje niewiele różniące się od anonimowych donosów. Nie przysporzą korzyści nauce takie oceny, które głównie mają na celu zaszkodzenie autorowi publikacji.

Wreszcie: recenzja, ujęta w złożonym z kilku punktów schemacie, ogranicza swobodę wypowiedzi recenzenta. Wiele przykładów dowodzi, że dla rozwoju nauki szczególnie cenne są recenzje rozbudowane, mające charakter artykułów recenzyjnych. Z otwartą przyłbicą podejmują dyskusje z poglądami przeciwnika, skłaniają go do wycofania się lub do obrony własnych poglądów.

Te i tym podobne przekonania, wyrażone na marginesie dyskusji poświęconej „Czasopismu Prawno-Historycznemu”, są wyrazem krytyki pod adresem dokonywanych ostatnio reform. Dążąc rzekomo do uproszczenia procesu awansu naukowego, mają na celu nie tyle rozwój nauki, co objęcie jej kontrolą. Jest to dążenie do ograniczenia tak niedawno odzyskanej autonomii szkolnictwa wyższego i całego środowiska naukowego.

Reformy, które już wpłynęły i nadal wpływać będą - choć, jak się okazuje, nie zawsze pozytywnie - na sytuację polskiej humanistyki, nie mogły pozostać bez wpływu na CPH. Również i ten periodyk objęty został systemem punktacyjnym i skłoniony został do spełnienia wszystkich jego wymogów. $\mathrm{Na}$ szczęście nie wpłynęło to na organizację $\mathrm{CPH}$, wytwarzającą się stopnio- 
wo i sprawdzoną w praktyce. Nadal na czele $\mathrm{CPH}$ stoi redaktor, aprobowany przez środowisko, w razie potrzeby powołujący do pomocy zastępcę oraz sekretarza. W razie potrzeby, także do pomocy, zbiera się Komitet Redakcyjny, ciało doradcze o charakterze koleżeńskim.

Obowiązki redaktora $\mathrm{CPH}$ pełnił do roku ubiegłego Henryk Olszewski, profesor Uniwersytetu Adama Mickiewicza w Poznaniu. Tam też mieści się lokal redakcji i jej archiwum. Profesor Henryk Olszewski związany jest z CPH od przełomu lat pięćdziesiątych i sześćdziesiątych ubiegłego wieku, najpierw jako publikujący na tych łamach autor, następnie jako pełniący kolejno odpowiedzialne funkcje. W 1963 roku przejął po profesorze Janie Wąsickim stanowisko sekretarza redakcji, choć obowiązki te pełnił nieformalnie już wcześniej. W 1978 roku, po zgonie ówczesnego redaktora, profesora Michała Sczanieckiego, przejął całość obowiązków redakcyjnych. Dorobek osiągnął imponujący: przygotował i wydał do chwili dzisiejszej 36 dwuzeszytowych tomów „Czasopisma”. Przetrwał burze polityczne lat 1969-1980 czy trudności lat 1990-2000, kiedy to z powodów nie tylko materialnych CPH wydawać mogło tylko jeden zeszyt rocznie. Nadeszły też wówczas czasy, kiedy konkurencją dla ogólnopolskiej pozycji CPH stały się „Studia” oraz „Zeszyty historycznoprawne", wydawane w poszczególnych ośrodkach.

Polityka redakcyjna minionych lat, kiedy obowiązywała cenzura oraz wyraźne wytyczne, wymagała działań ostrożnych i wyważonych. Całe pola badawcze, zagadnienia czy publikacje niektórych uczonych były skazywane na banicję bądź przeciwnie, były szczególnie popierane. Kiedy nadchodziły czasy odwilży lub ochłodzenia, kiedy wreszcie ustrój „demokracji ludowej” chylić się począł ku upadkowi, stopniowo powracała swoboda badawcza.

Regularna praca redakcyjna stwarzała nieustanne pasmo kłopotów materialnych i organizacyjnych, a także zatargów środowiskowych i koleżeńskich. Redaktor stawiał im czoła ze spokojem, dyplomacją i kulturą. Starał się zapewnić, by badacze zawsze mieli możność publikacji wyników swoich badań, aby nigdy nie brakowało miejsca dla poszczególnych dyscyplin, inicjował niektóre opracowania. Publikowane od czasu do czasu informacje o strukturach, kadrze, planach badań i dydaktyce poszczególnych katedr były istotnym czynnikiem, ściśle wiążącym dyscypliny prawnohistoryczne w poszczególnych ośrodkach, instytucjach i katedrach. Starał się, aby nie wygasały kontakty międzynarodowe, zwłaszcza z uczonymi francuskimi, niemieckimi i austriackimi. I wreszcie: aby publikacje nie schodziły poniżej zasługującego na dobrą ocenę poziomu i nie popadały w nadmierne przyczynkarstwo. Aby dyskusje naukowe toczyły się w myśl zasady: fortiter in re, suaviter in modo ${ }^{11}$.

Staranną uwagą otoczył redaktor dział kroniki, zmierzając do tego, aby przez wszystkie te lata stanowił podstawę pod dzieje nauk historycznopraw-

11 W czynie mocno, łagodnie w sposobie. 
nych. Kronikę tę uzupełniają „Rozmowy w redakcji”, prowadzone przez redaktora lub jego najbliższych współpracowników z przedstawicielami starszego pokolenia badaczy. Opisują oni we wspomnieniach swoją drogę naukową i - subiektywnie oczywiście - ówczesne warunki pracy uniwersyteckiej.

Całość informacji kronikarskich i rozmów redakcyjnych stworzyła już bogaty zasób informacji nie tylko dla historii naszych dyscyplin, ale i warunków pracy oraz dziejów uniwersyteckich w wieku dwudziestym. Podjęcie takiego opracowania jest już tylko kwestią czasu.

Działalność poprzedniego redaktora, profesora Michała Sczanieckiego, została odpowiednio podsumowana ${ }^{12}$. Nie sposób więc dopuścić, żeby w „Czasopiśmie”, z obowiązku kronikarskiego notującym drobne nawet zdarzenia, dotyczące dyscyplin prawnohistorycznych, pominięty został fakt zmiany na stanowisku redaktora i nie podjęto by próby oceny jego dorobku organizacyjnego i naukowego.

Profesor Henryk Olszewski, który nadał „Czasopismu” poziom i znaczenie, jakie od kilkudziesięciu lat zasłużony ten periodyk zachowuje, podjął bowiem decyzję, iż z chwilą opublikowania zeszytu 2 tomu LXVI rezygnuje ze stanowiska redaktora. Stało się to na konferencji w dniu 9 września 2014 roku. Komitet Redakcyjny CPH przyjął to oświadczenie ze smutkiem. Gdyby przyjaciele, koledzy i uczniowie Henryka Olszewskiego rozłożyli jego dorobek redakcyjny na katedrze, zza której prowadzi swoje wykłady, byłyby to 72 volumeny 36 tomów. Podjęty więc został jednomyślny wniosek, aby następne posiedzenie Komitetu Redakcyjnego złożyło mu wyrazy wdzięczności za wieloletni i tak twórczy wysiłek.

SOME REFLECTIONS ON THE SCIENCE OF THE HISTORY OF LAW, THE “CZASOPISMO PRAWNO-HISTORYCZNE” AND ITS EDITOR-IN-CHIEF

\section{Summary}

In 2014, "Czasopismo Prawno-Historyczne" (CHP) celebrated its $65^{\text {th }}$ birthday and released its $65^{\text {th }}$ jubilee volume. The jubilee was also an occasion to hold a special ceremonious meeting of the CHP's Editorial Board, during which certain assessments were made to determine the role which the Journal played in the over two hundred years" history of legal and historic studies in Poland. "Czasopismo PrawnoHistoryczne" was founded in 1948 by an eminent scholar Zygmunt Wojciechowski, and was intended to bring together the community of law historians that had suffered irreparable losses during the WWII. The Journal represented all sub-disciplines of law, and included ancient and Roman law, the history of political regimes, cannon

12 J. Bardach, H. Olszewski, Michat Sczaniecki 1910-1977 (CPH, t. XXX, z. 1, 1978 r., s. 16-17). 
law, the history of judicial law, and the history of legal sciences. It also played an important role of an ambassador of the science of the history of law, globally, enjoying contributions made by the most outstanding Polish and European scholars. Scientific achievements as well as greatest scientific controversies have been published, and the Journal lived through some very good but also through some bad times. Currently, CHP faces new challenges and some threats as well. Legal pragmatism and the shift in generations, the reforms in the syllabi and the reduction of the numbers of hours devoted to the teaching of the history of law, bureaucracy and formality in the state policy, reduction in the posts available to historians of law, plus the moving away from the focus on the past in favour of focusing on the newest times and contemporary history in the teaching of law are but a few of the main current threats. And yet, despite the above trends, the Scientific Committee of the CHP is positively determined and convinced that maintaining high standards of scholarly work and the teaching of law should continue to be the priority and focus of its work and efforts.

\section{RÉFLEXIONS SUR L'HISTOIRE DU DROIT, CPH ET SON RÉDACTEUR}

\section{Résumé}

En 2014, CPH a fêté son $65^{\circ}$ anniversaire, le jubilé ayant été en particulier mis en relief dans le volume $\mathrm{N}^{\circ} 65$. L'anniversaire a permis au Comité rédactionnel de se réunir pour une séance solennelle durant laquelle il a évalué le rôle du magazine dans l'histoire de plus de deux cents ans des sciences historico-juridiques en Pologne. Créé en 1948 par Zygmunt Wojciechowski, un savant éminent, le magazine avait pour objectif, tout au début, l'intégration des historiens du droit, le milieu qui a subi des pertes irrémédiables pendant la deuxième guerre mondiale. Et il joue à l'époque son rôle très bien surtout parce qu'il représente toutes les sous-disciplines de l'histoire du droit: droit antique et droit romain, histoire du régime, droit canon, histoire du droit judiciare et histoire des sciences juridiques. Il devient l'ambassadeur de l'histoire du droit dans le monde. Les hommes de sciences polonais et européens les plus remarquables ont travaillé avec $\mathrm{CPH}$. Sur ses pages ont été présentés les résultats du travail scientifique d'une part et les sujets de controverse de l'autre. La revue a connu des hauts et des bas. A présent, $\mathrm{CPH}$ doit faire face à plus d'un danger. Le pragmatisme juridique et le changement de générations, mais aussi les changements introduits dans l'enseignement universitaire consistant à réduire le nombre d'heures de l'histoire du droit enseignée, la bureaucratie et le formalisme de la politique menée par l'État, la réduction des équipes d'historiens du droit, le poids des recherches reporté désormais sur les époques les plus récentes et l'histoire contemporaine, voici les raisons principales des risques susmentionnés. Cependant, le Comité rédactionnel exprime sa conviction que maintenir la haute qualité des sciences et de l'enseignement du droit fait partie des priorités du travail rédactionnel. 